\title{
Neuroacanthocytosis diagnózisa új generációs exom-szekvenálással
}

\author{
Hadzsiev Kinga dr. ${ }^{1,2}$ - Szőts Mónika dr. ${ }^{2}$ \\ Fekete Anett dr. ${ }^{1}$ - Balikó László dr. ${ }^{3}$ - Kim Boycott dr. ${ }^{4}$ \\ Nagy Ferenc dr. ${ }^{2}$ - Melegh Béla dr. ${ }^{1}$
}

${ }^{1}$ Pécsi Tudományegyetem, Általános Orvostudományi Kar, Klinikai Központ, Orvosi Genetikai Intézet, Pécs

${ }^{2}$ Somogy Megyei Kaposi Mór Oktató Kórház, Neurológiai Osztály, Kaposvár

${ }^{3}$ Zala Megyei Szent Rafael Kórház, Neurológiai Osztály, Zalaegerszeg

${ }^{4}$ Children's Hospital of Eastern Ontario Research Institute Inc., Ottawa, Kanada

A jelen tudományos közleményt a szerzök

a Pécsi Tudományegyetem alapitásának 650. évfordulója tiszteletére közlik.

\begin{abstract}
Egy Huntington-betegségre utaló tünetegyüttest produkáló betegben a huntingtin mutáció negatív volta miatt nemzetközi kollaboráció keretén belül exom-szekvenálás (whole exome sequencing - WES) készült. Betegünkben a WES során a VPS13A gén 34 exonjában egy homozigóta G>A cserét detektáltunk, ami az 1301-es kodonon egy prematurus stopkodont eredményez. Az eltérés ismert patogén mutáció. Közleményünkben a módszer fontosságára szeretnénk rámutatni nagyon ritka, nem specifikus megjelenést mutató neurológiai kórképek diagnosztikájában. Orv Hetil. 2017; 158(42): 1681-1684.
\end{abstract}

Kulcsszavak: WES, acanthocytosis, chorea, VPS13A

\section{Neuroacanthocytosis diagnosis with new generation whole exome sequencing}

In a patient with marked symptoms of Huntington disease after the huntingtin testing, which gave normal result, a whole exome sequencing (WES) has been performed based on an international collaboration. A homozygous $\mathrm{G}>\mathrm{A}$ nucleotid change in the exon 34 of the VPS13A gene has been detected with WES, a mutation resulting in a premature stop codon at the position 1301. This change is a known pathogenic mutation. The aim of this article is to draw attention on the importance of the WES in the diagnosis of rare neurological diseases without any specific symptoms.

Keyword: WES, acanthocytosis, chorea, VPS13A

Hadzsiev K, Szőts M, Fekete A, Balikó L, Kim B, Nagy F, Melegh B. [Neuroacanthocytosis diagnosis with new generation whole exome sequencing]. Orv Hetil. 2017; 158(42): 1681-1684.

(Beérkezett: 2017. augusztus 10.; elfogadva: 2017. szeptember 7.)

\section{Rövidítések}

ASHG = American Society of Human Genetics (Amerikai Humángenetikai Társaság); ChAc = chorea-acanthocytosis; ESHG = European Society of Human Genetics (Európai Humángenetikai Társaság); ExAC Browser = Exome Aggregation Consortium; HDL2 = Huntington kór-szerü betegség 2-es típusa; MLS = McLeod-szindróma; NGS = next-generation sequencing (új generációs szekvenálás); NHLBI Exome Sequencing Project (Exome Variant Server); NS = neuroacanthocytosis- szindrómák; PKAN = pantotén-kináz-asszociált neurodegeneráció; WES = whole exome sequencing (exom-szekvenálás); WGS $=$ whole genome sequencing (teljesgenom-szekvenálás)

A mozgászavarok változó életkorban kezdődő, széles fenotípusos spektrumot felölelő betegségcsoport, egyre több kórkép hátterében mutatható ki genetikai eltérés. Idetartoznak a neuroacanthocytosis-szindrómák (NS), 
amik egy heterogén betegségcsoportot alkotnak - fö tünetük az idegrendszeri eltérések mellett a vörösvértestek acanthocytosisa. Acanthocytának nevezzük azokat a kóros morfológiájú vörösvértesteket, amik tüskeszerü plazmanyúlványokkal rendelkeznek. Nevét a görög $\alpha \kappa \alpha \nu \Theta \alpha$ szóból nyerte, ami tüskét jelent, és egészséges egyénekben nem észlehető. Az érintett betegek vérkenetében 10-30\% arányban észlelhetők.

Az NS két fó csoportját különíthetjük el: az egyik csoportban a basalis ganglion degenerációja, mozgászavarok, mentális hanyatlás és pszichiátriai tünetek észlelhetők, a másik csoportban az E-vitamin-malabszorpcióhoz vezető a/hypobetalipoproteinaemia miatt perifériás neuropathia és szenzoros ataxia észlelhető [1]. Ebben a csoportban mozgászavar nem képezi a tünetek részét, ezért jelen közleményünkben ezt a továbbiakban nem részletezzük.

Az első csoportban négy jól elkülöníthető kórkép definiálható, nevezetesen az autoszomális recesszív öröklésmenetű chorea-acanthocytosis (ChAc), az X-hez kötött öröklődésű McLeod-szindróma (MLS), a pantoténkináz-asszociált neurodegeneráció (PKAN) és a Huntington-kór-szerü betegség 2-es típusa (HDL2) [1, 2].

Előfordulási gyakoriságukat tekintve a ritka kórképek közé tartoznak, azonban - nagy valószínűség szerint mindegyik formájuk aluldiagnosztizált. A ChAc pontos incidenciája nem ismert, gyakrabban fordul elő Japánban, valószínúleg founder effektus miatt [3], de más, földrajzilag zárt populációban, mint például a francia-kanadai populációnál is gyakoribb az előfordulása [4]. Az MLS prevalenciája világszerte egyenletes, néhány száz család ismert [5]. A két másik, a csoportba tartozó kórkép lényegesen ritkább, a PKAN feltételezett gyakorisága 1-3/1 000 000, míg a HLD2-ből mindössze 50 családot fedeztek fel világszerte [6].

ChAc, ami közleményünk témáját képezi, első leírása Levine-től, 1968-ból [7], majd Critchley-től, 1970-ből származik [8]. A kórkép ezért a szakirodalomban LevineCritchley-szindrómaként is ismert.

\section{Esetismertetés}

Betegünket több éven keresztül követtük, míg sikerült felállítani a diagnózist. A roma származású beteg gyermek- és fiatalkori anamnézisében enyhe mentális retardáció miatti gondozás szerepelt, azonban szakmát tanult. Tünetei 37 éves korában kezdődtek nyugtalansággal, zavartsággal, amihez a későbbiekben dühkitörések és kényszermozgások csatlakoztak. A progresszív jellegú choreiform túlmozgások miatt elvégzett koponya-MRvizsgálat a jobb frontalis lebenyben subcorticalisan elhelyezkedő szoliter fehérállományi laesiótól eltekintve kóros eltérést nem mutatott.

Állapota folyamatosan progrediált, jelenleg - 44 éves korában - járásképtelen, nyelészavar miatt szondán keresztül táplálható, finom hullámú horizontális nystag- mus, alszári hypotonia és atrophia észlelhető, kontaktusba nehezen vonható, hangulata torpid.

Intézetünkben első vizsgálatára 40 éves korában került sor a több éve progrediáló járászavar, ataxia, túlmozgások, mentális hanyatlás és elkent beszéd mellett észlelhető egyre kifejezettebb szkizoaffektív zavar miatt. Családi anamnéziséből kiemelendő, hogy öccsénél és apai ágú másodunokatestvérénél hasonló neurológiai tünetek kezdődtek. Dysmorphiás státuszában kiugró homlokcsont és prominens fülek voltak észlelhetők, egyebekben jelentős eltérést nem észleltünk. A klinikum alapján első lépésként a fragilis X-szindróma került kizárásra. A beteg állapota progrediált, hangulat- és viselkedészavarok jelentek meg, és új tünetként katéterezést igénylő hólyagmúködési zavar alakult ki. Ekkor - a romló neuropszichiátriai tünettan alapján - Huntington-kór irányába vizsgáltuk, azonban kóros eltérést, triplet repeat expanziót nem találtunk.

A klinikai tünetek további romlása miatt nemzetközi kollaborációban megtörtént a beteg DNS-ének exomvizsgálata, amelynek során a VPS13A génben a homozigóta nonsense c.3903G>A (p.Trp1301*) mutációt sikerült kimutatni (1. ábra).

\section{Vizsgálómódszer}

Az exom-szekvenálás (whole exome sequencing - WES) során a beteg DNS-éból az összes kódoló szakasz vizsgálatára került sor, Agilent SureSelect $50 \mathrm{Mb}$ exome enrichment kittel. A szekvenálás Illumina HiSeq 2000 készülékkel történt, 80-szoros átlagos lefedettséggel.

\section{Megbeszélés}

Betegünkben a WES során a VPS13A gén 34-es exonjában egy homozigóta $\mathrm{G}>\mathrm{A}$ cserét detektáltunk, ami az 1301-es kodonon egy prematurus stopkodont eredményez. Az eltérés ismert patogén mutáció [9]. Ez a mutáció feltételezetten egészséges egyénekben az Exome Aggregation Consortium (ExAC Browser) és az NHLBI Exome Sequencing Project (Exome Variant Server) vizsgálatai során nem volt kimutatható.

A choreaacanthocytosis-szindróma egy ritka, autoszomális recesszív módon öröklődő neurodegeneratív kórkép. A betegséget a 360 kDa méretû VPS13A, más néven chorein fehérje funkcióvesztése okozza, ez a fehérje csaknem teljes mértékben hiányzik az érintett betegekben. A gén a 9q21 kromoszomális régióban helyezkedik el, 73 exont tartalmaz és $250 \mathrm{~kb}$ nagyságot fed le, hotspot régiója nem ismert, számos különböző mutációját írták le az érintett betegekben. A fehérje expresszióját agyban, szívben, vázizomban és a vesében detektálták [9], fó funkciója a cytoskeletonregulációban van. $K u$ rano és mtsai [10] bizonyították, hogy a VPS13A fehérje részt vesz az autophagia különböző szinten történő regulálásában. Korábbi vizsgálatokban más munkacsoportok [11-13] kimutatták, hogy a VPS13A elcsendesítése 


\section{c.3903G>A}

p.W1301X

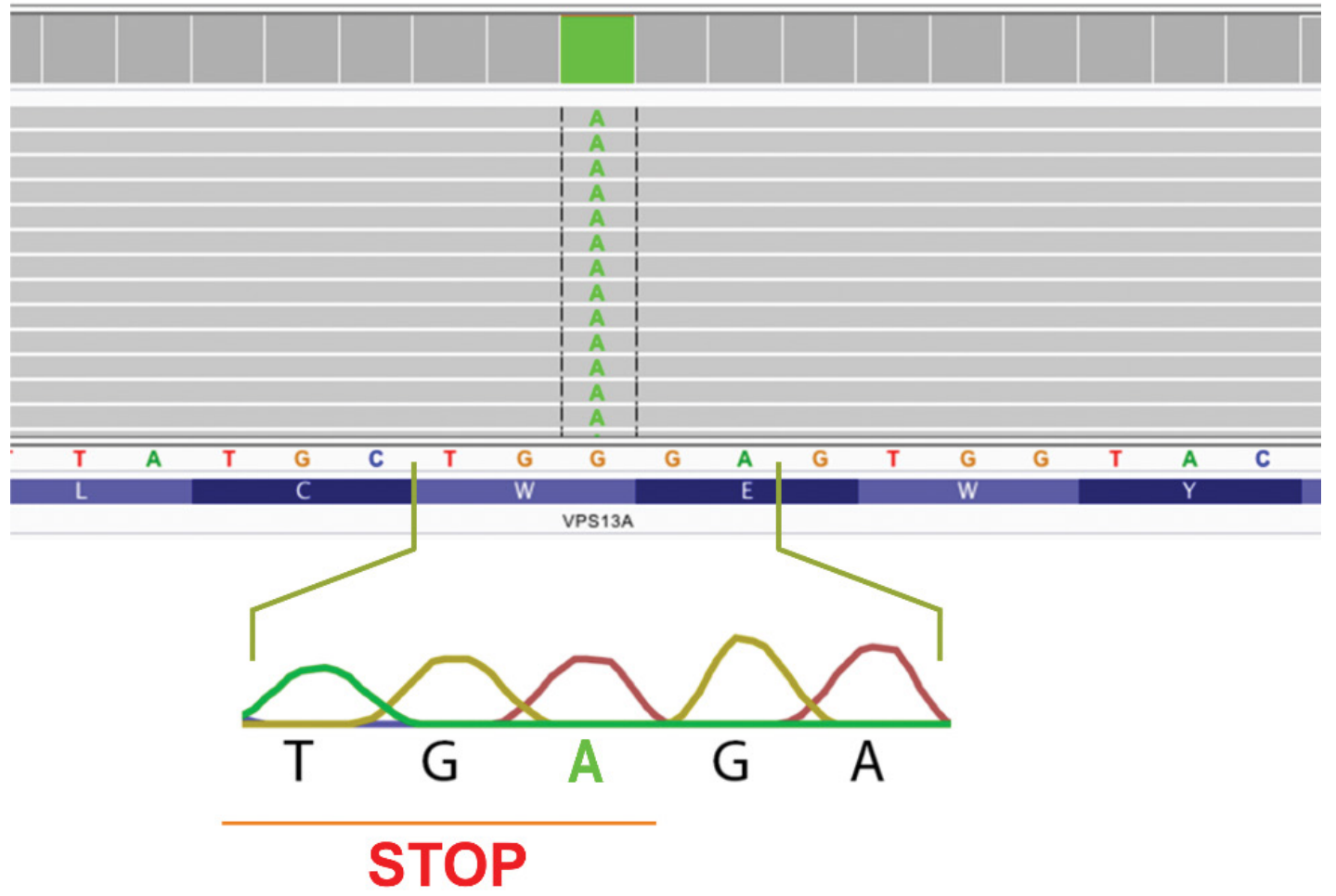

1. ábra

| A VPS13A génben NGS-módszerrel észlelt mutáció és ennek Sanger-szekvenálással történt verifikációja

erythrocyta- és vascularis endothelsejtekben a sejt alakjának megváltozását és a cytoskeleton-architektúra változását eredményezi. Mindezek alapján egyértelmú, hogy az autophagia károsodott múködése felelős a VPS13-aszszociált betegségek, elsősorban a chorea-acanthocytosis kialakulásáért.

$\mathrm{Az}$ új generációs szekvenálási (next-generation sequencing - NGS) eljárások egyre szélesebb körben történő elterjedése paradigmaváltást hozott mind az új betegségokozó gének felfedezésében, mind a genetikai betegségek minél koraibb diagnosztizálásában. Az egyik fontos területe a teljesgenom-szekvenálás (whole genome sequencing - WGS), amikor csaknem a teljes humán genomot vizsgáljuk. Ez a módszer, a kapott hatalmas adattömeg miatt, inkább csak a kutatás terén használatos, hiszen bizonyos eltérések interpretálása komoly nehézséget jelent. Azonban a másik területe, a cikkünkben korábban már említett WES egyre szélesebb körben használatos a diagnosztikában is, hiszen ritka mendeli betegségben szenvedő betegek vizsgálata során különböző munkacsoportok 22-46\% közötti találati arányról számolnak be [14-16]. A Magyarországon 2008 óta érvényben lévő 2008/XXI-es, a humángenetikai adatok védelméről, a humángenetikai vizsgálatok és kutatások, valamint a biobankok múködésének szabályairól rendelkező törvény jelentősége az új generációs vizsgálómódszerek egyre szélesebb körben való elterjedése miatt megnőtt. Ahogy már korábban is említettük, ezekkel a módszerekkel (WES, WGS) a genetikai állomány jelentős része kerül vizsgálatra, így elkerülhetetlenek az úgynevezett incidentális találatok. Ezeknek az interpretálása - tekintve, hogy a klinikai tünetektől függetlenek - számos etikai, jogi kérdést vetnek fel, ezért mind az amerikai, mind az európiai humángenetikai társaságok (ASHG, ESHG) részletes ajánlást dolgoztak ki ezzel kapcsolatosan. Ezért is nagy jelentőségű a fent említett törvény és annak betartása a genetikai vizsgálatok indikálása kapcsán. Az új generációs módszerek pontos ismerete és a megfelelő vizsgálómódszer kiválasztása értelemszerúen a klinikai genetikus kompetenciája, így tudjuk az amúgy igen magas költségeket optimalizálni. Sajnálatos módon jelen pillanatban Magyarországon egyetlen új generációs vizsgálómódszer sem érhető el a Nemzeti Egészségbiztosítási Alapkezelő finanszírozásában. Remélhetőleg ez rövidesen változni fog, hiszen mind a tudásbeli, mind a technikai feltételek hazánkban is rendelkezésre állnak.

Közleményünk célja egyrészt az volt, hogy bemutassunk egy ritka, mozgászavarral járó rendellenességet. Másik célunk, ami talán az olvasók szélesebb körét érinti, az volt, hogy felhívjuk a figyelmet egy új vizsgálóeljárásra, nevezetesen az exom-szekvenálásra, ami már hazánkban is elérhető és a ritka betegségek esetén segítségünkre lehet a pontos kóroki diagnózis felállításában, ezen keresztül a betegek jobb ellátásában. 
Anyagi támogatás: A közlemény megírása anyagi támogatásban nem részesült.

Szerzői munkamegosztás: K. B., H. K.: A molekuláris genetikai vizsgálatok elvégzése, értékelése. H. K., Sz. M., B. L., N. F.: Betegvizsgálat. H. K., F. A.: A kézirat megszövegezése. M. B.: A kézirat áttekintése. A cikk végleges változatát valamennyi szerző elolvasta és jóváhagyta.

Érdekeltségek: A szerzőknek nincsenek érdekeltségeik.

\section{Irodalom}

[1] Rampoldi L, Danek A, Monaco AP. Clinical features and molecular bases of neuroacanthocytosis. J Mol Med. 2002; 80: 475491.

[2] Jung HH, Danek A, Walker RH. Neuroacanthocytosis syndromes. Orphanet J Rare Dis. 2011; 6: 68.

[3] Ueno S, Maruki Y, Nakamura M, et al. The gene encoding a newly discovered protein, chorein, is mutation in chorea-acanthocytosis. Nat Genet. 2001; 28: 121-122.

[4] Dobson-Stone C, Velayos-Baeza A, Jansen A, et al. Identification of a VPS13A founder mutation in French Canadian families with chorea-acanthocytosis. Neurogenetics 2005; 6: 151-158.

[5] Jung HH, Danek A, Frey BM. McLeod syndrome: a neurohaematological disorder. Vox Sang. 2007; 93: 112-121.

[6] Margolis RL, Holmes SE, Rosenblatt A, et al. Huntington's disease-like 2 (HDL2) in North America and Japan. Ann Neurol. 2004; 56: 670-674.

[7] Levine IM, Estes JW, Looney JM. Hereditary neurological disease with acanthocytosis: a new syndrome. Arch Neurol. 1968; 19: $403-409$
[8] Critchley EM, Nicholson JT, Betts JJ, et al. Acanthocytosis, normolipoproteinaemia and multiple tics. Postgrad Med J. 1970; 46: 698-701.

[9] Rampoldi L, Dobson-Stone C, Rubio JP, et al. A conserved sorting-associated protein is a mutant in chorea-acanthocytosis. Nat Genet. 2001; 28: 119-120.

[10] Kurano Y, Nakamura M, Ichiba M, et al. In vivo distribution and localization of chorein. Biochem Biophys Res Commun. 2007; 353: $431-435$.

[11] Muñoz-Braceras S, Calvo R, Escalante R. TipC and the choreaacanthocytosis protein VPS13A regulate autophagy in Dictyostelium and human HeLa cells. Autophagy 2015; 11: 918-927.

[12] Alesutan I, Seifert J, Pakladok T, et al. Chorein sensitivity of actin polymerization, cell shape and mechanical stiffness of vascular endothelial cells. Cell Physiol Biochem. 2013; 32: 728-742.

[13] Föller M, Hermann A, Gu S, et al. Chorein-sensitive polymerization of cortical actin and suicidal cell death in chorea-acanthocytosis. FASEB J. 2012; 26: 1526-1534.

[14] Sawyer SL, Hartley T, Dyment DA, et al. Utility of whole-exome sequencing for those near the end of the diagnostic odyssey: time to address gaps in care. Clin Genet. 2016; 89: 275-284.

[15] Soden SE, Saunders CJ, Willig LK, et al. Effectiveness of exome and genome sequencing guided by acuity of illness for diagnosis of neurodevelopmental disorders. Sci Transl Med. 2014; 6: 265 ral68.

[16] Lee H, Deignan JL, Dorrani N, et al. Clinical exome sequencing for genetic identification of rare Mendelian disorders. JAMA 2014; 312: 1880-1887.

(Hadzsiev Kinga dr., Pécs, József A. u. 7., 7623 e-mail: hadzsiev.kinga@pte.hu)

\section{"Fratrum inter irae sunt acerbissimae." (Testvérek közötti harag a legkeservesebb.)}

